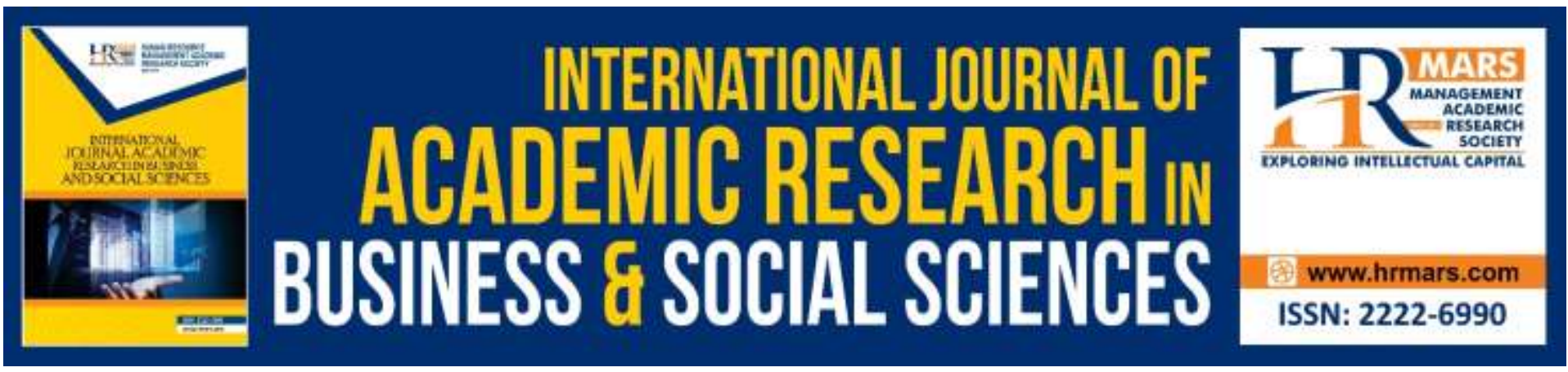

\title{
The Comparison between Fine Motor Skills Traditional Activities and Multi-Touch Gestures Screen Design: Expert Reviews
}

Fadhlina Mohd Razali, Nor Azah Abdul Aziz, Roznim Mohamad Rasli, Nur Farah Zulkefly, Noor Hidayah Azmi

To Link this Article: http://dx.doi.org/10.6007/IJARBSS/v9-i14/6503

DOI: $10.6007 /$ IJARBSS/v9-i14/6503

Received: 02 September 2019, Revised: 25 September 2019, Accepted: 02 October 2019

Published Online: 20 October 2019

In-Text Citation: (Razali, Aziz, Rasli, Zulkefly, \& Azmi, 2019)

To Cite this Article: Razali, F. M., Aziz, N. A. A., Rasli, R. M., Zulkefly, N. F., \& Azmi, N. H. (2019). The Comparison between Fine Motor Skills Traditional Activities and Multi-Touch Gestures Screen Design: Expert Reviews. International Journal of Academic Research in Business and Social Sciences, 9(14), 39-51.

Copyright: (C) 2019 The Author(s)

Published by Human Resource Management Academic Research Society (www.hrmars.com)

This article is published under the Creative Commons Attribution (CC BY 4.0) license. Anyone may reproduce, distribute, translate and create derivative works of this article (for both commercial and non-commercial purposes), subject to full attribution to the original publication and authors. The full terms of this license may be seen

at: http://creativecommons.org/licences/by/4.0/legalcode

Vol. 9, No. 14, Special Issue: Education 4.0: Future Learning, Pg. 39 - 51

Full Terms \& Conditions of access and use can be found at http://hrmars.com/index.php/pages/detail/publication-ethics 


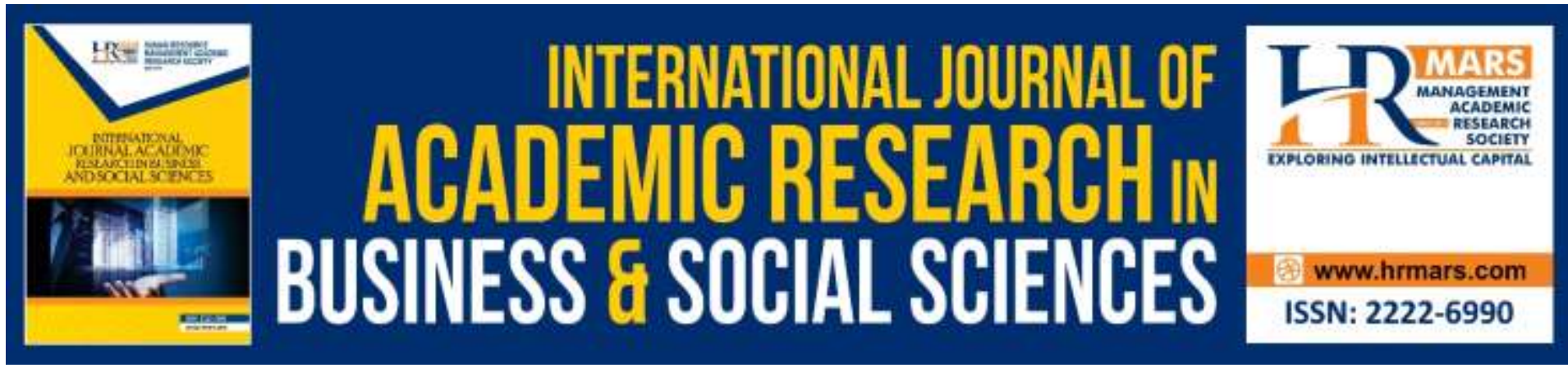

\title{
The Comparison between Fine Motor Skills Traditional Activities and Multi-Touch Gestures Screen Design: Expert Reviews
}

\author{
Fadhlina Mohd Razali ${ }^{1}$, Nor Azah Abdul Aziz², Roznim \\ Mohamad Rasli ${ }^{3}$, Nur Farah Zulkefly ${ }^{4}$, Noor Hidayah Azmi ${ }^{6}$ \\ ${ }^{1}$ Sultan Idris Education University, ${ }^{2}$ Sultan Idris Education University, ${ }^{3}$ Sultan Idris Education \\ University, ${ }^{4}$ Sultan Idris Education University, ${ }^{5}$ Sultan Idris Education University \\ Email: fadhlina@fskik.upsi.edu.my, azah@fskik.upsi.edu.my,roznim@fskik.upsi.edu.my, \\ nurfarahzulkefly@gmail.com, hidayah@fskik.upsi.edu.my
}

\begin{abstract}
The purpose of this study is to acquire expert reviews regarding a comparison between fine motor skills traditional activities with multi-touch gestures screen design. The multi-touch gestures enables children to perform multiple finger gestures such as free rotate, pinch and spread on touch screen design. The gestures are often selected because it is similar to reallife movements. Furthermore, it can enhance the interaction between users and virtual objects. Free rotate gesture enables children to rotate the objects on screen. Pinch gesture enables children to focus on the objects on screen by moving two fingers toward each other. Spread gesture enables children to make the objects look bigger on screen by moving two fingers away from each other. As these gestures involved small muscle movements, it was believed to be related to fine motor skills development. Therefore, this study aimed to get expert reviews about the pre-school children's fine motor skills development by comparing the fine motor skills traditional activities with multi-touch gestures screen design. The research methodology for this research was qualitative. Interview sessions were been conducted to one domain expert and two teachers from National Children Development Research Centre (NCDRC). The interview consisted of twelve questions and divided into three sections referred on three gestures: free rotate, pinch and spread. The findings showed that the multitouch gestures was related to the fine motor skills development but in small scale. As for conclusion, the multitouch gestures especially free rotate, pinch and spread is an important factor that should be be taken into consideration when designing mobile apps for pre-school children.
\end{abstract}

Keywords: Free Rotate, Pinch, Spread, Fine Motor Skills. 


\section{Introduction}

Children begin to use their hands since they were born to explore their own bodies and the world around them. Their fine motor skills develop when the entire body starts moving and becomes more stable. Children can rapidly manipulate objects or execute commands by means of their fingers and hands (Kammer et al., 2010). Children are more open to instruction and more likely to learn by encouraging them to use their hands (Katrina, 2015). Thus, these hands' activities can be considered as an assistive approach in fine motor skills development (Fine Motor Skills, 2016). According to Nachiappan, Jantan \& Shukor (2008), in the early stages of childhood (from two years until six years), their large muscles have grown but small muscles are still not developing perfectly.

As technology increased laterally with touch screen technologies, the children were also exposed to use it. The touch screen is not only used in the communication process but also in early childhood education (Flewitt, Messer, \& Kucirkova, 2015). According to Omar (2010), this technology was quite a popular trend among children in Malaysia. Children often see as a grown up groups incessantly with the technology which motivate them to practically use it. They will experience a better learning environment if they handle it in a right way particularly for their fine motor skills development.

Although previous researchers began studying the touch screen of children interaction in a wider scale, the scope of the researches were different (Crescenzi, Jewitt \& Price, 2014). Most researchers were studying the ability of children to use touch-screen devices such as the iPad and tablet but less studies focusing on the use of the technology towards fine motor skills development of children. However a study by Lin, Cherng \& Chen (2017) proof that there were positive relationship between children who actively use the touch screen with motor development.

Therefore this study aimed to investigate the fine motor skills development of preschool children when using multi-touch gestures on screen design based on expert reviews. It compares the fine motor skills traditional activities with multi-touch gestures screen design. The comparison will motivate designers and developers to embed the multi-touch gestures design such as free rotate, pinch and spread when designing mobile apps for pre-school children as the movements of those gestures were similar to fine motor skills traditional activities.

\section{Objectives}

This study is to get expert reviews about the children's fine motor skills development by comparing the fine motor skills traditional activities with multi-touch gestures screen design.

\section{Multi-Touch Gestures}

A touch-screen technology is an electronic visual display that can detect the presence and location of a touch within the display area. The term generally refers to touching the display of the device with finger or hand (Jain, Bhargava \& Rajput, 2013). There were two categories of the touch screen such as single-touch gestures and multi-touch gestures which involved 7 major finger movements (Aziz, 2013). 
As indicated by Aziz (2013), there are 7 common gestures used in children's apps which are tap, drag/slide, free rotate, drag \& drop, pinch, flick and spread. However, in most commercialize pre-school mobile apps, the only gestures applied are tap and slide/drag operations. Thus, other multi-touch gestures such as free rotate, pinch and spread gestures are infrequently used. Figure 1, Figure 2 and Figure 3 display the movement of free rotate, pinch and spread gestures implemented on touch screen design.

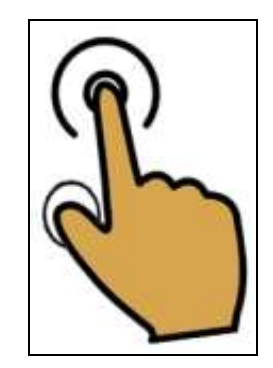

Figure 1. Free rotate gestures

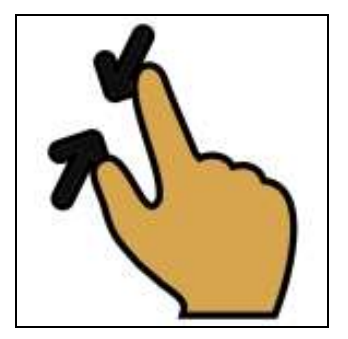

Figure 2. Pinch gestures

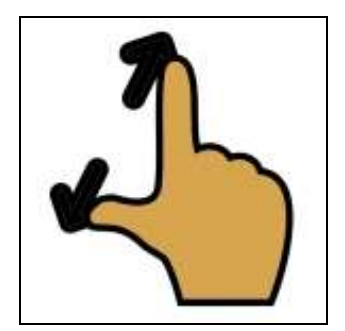

Figure 3. Spread gestures

Figure 1 shows the free rotate gesture which requires the children to twist their fingers. Figure 2 shows the pinch gesture which requires the children to use two fingers and bring them closer on the surface. Figure 3 shows the spread gesture which requires the children to touch the surface with two or more fingers and move them apart. 
The multi-touch gestures technologies allow devices to react on touch input across touch screen display areas synchronously. It is a method of giving input on the touch screen that allows two or more fingers to be used simultaneously. Users can manipulate objects and execute instructions in mobile apps only by using their fingers and hands. Nevertheless, the ability to use all finger movements depends on the age of the children. Based on previous study by Aziz (2013), the children aged 2 years struggling to make multi touch gestures such as flick, slide, drag \& drop, rotate, pinch and spread. Children aged 3 also having the same problem during the multi touch of rotate, pinch and spread while children aged 4 to 12 years old can perform all of 7 major finger movements.

However, children in the 21st century are capable of learning to use touch-screen and make gestures despite various difficulties. They will experience a well learning setting if they were given appropriate touch screen gestures and handle it in a right way. Agostinho et al. (2015) mentioned that finger tracing on tablet device could enhance learning performance which support mathematical problem solving. Similarly, a study found that participants in the drag condition were more accurate than those in the tap condition which asked participants to complete a number line estimation task by either tapping or dragging on a tablet (Dubé \& McEwen, 2015).

As it support the learning setting, appropriate touch screen gestures also had positive relation with motor development. Based on the study by Lin, Cherng \& Chen (2017) that investigated the relationship between the use of touch screen by children and the achievement level of motor development, data were collected through an online survey (online survey) by 715 parents with children aged 6 months to 3 years. 19 to 36 months is the age of the first children to use the touch screen and correlated significantly with fine motor skills (stacking blocks), with significant value, $p=0.03$. Positive relationship indicated that children who actively use the touch screen caused the increase in motor development and can be observed with real objects. Therefore, the use of touch-screen such as scrolling on the display screen related to the early achievement of the children fine motor skills development.

\section{Fine Motor Skills}

Fine motor skills are very important in children development. This skill is needed to help children control a writing instrument steadily. It is the foundation for children before they learn to write by using their hands. Hence, it is vital in order to have a proper pencil grasp and self-control towards writing instrument (Developing Motor Skills, 2016).

Fine motor skills are the ability to make movements using small muscles in hands, wrists and fingers. It involves subtle movements that enable children to manipulate objects such as mixing colours using paint and fingers or water drops with suction cups. Such movement is similar with the movement in multi-touch gestures design, for instance the free rotate, pinch and spread gestures. Table 1 shows the comparison between fine motor skills traditional activities with multi-touch gestures screen design which has similarities in its movements. 
Children use their fine motor skills especially when holding small items, buttoning clothing, turning pages, eating and cutting with scissors, which involves hand-eye coordination. Such activities can be learned over a period of time with a lot of practice only.

Table 1: Comparison between fine motor skills traditional activities with multi-touch gestures screen design.

\begin{tabular}{|c|c|c|}
\hline No & Traditional Activities & $\begin{array}{l}\text { Multi-touch } \\
\text { Screen Design }\end{array}$ \\
\hline 1. & $\begin{array}{l}\text { - Van Gogh Style Finger-Paint Printing } \\
\text { Children simply swirling and mixing colours } \\
\text { using paint and fingers. } \\
\text { - Lavender and Glitter Sensory Salt } \\
\text { Hands made lovely swirls and patterns. }\end{array}$ & $\begin{array}{l}\text { Free rotate gesture } \\
\text { (Requires the children to } \\
\text { twist their fingers on the } \\
\text { screen) }\end{array}$ \\
\hline 2. & $\begin{array}{l}\text { Water Drops with Suction Cups } \\
\text { Children use a finger grasp (involve two } \\
\text { fingers) to squeeze one drop of colour water } \\
\text { into each little bowl on the dish. } \\
\text { - Bean Gluing } \\
\text { Children draw a simple picture on a piece of } \\
\text { paper with a pencil. They trace the pencil lines } \\
\text { with beads. They glue the beads onto the } \\
\text { design. Gripping the beads with their fingers is } \\
\text { good fine motor practice. }\end{array}$ & $\begin{array}{l}\text { Pinch gesture } \\
\text { (Requires the children to use } \\
\text { two fingers and bring them } \\
\text { closer on the surface) }\end{array}$ \\
\hline 3. & $\begin{array}{l}\text { - Spreading Sand } \\
\text { Sand art is a great fine motor activity } \\
\text { because children can pinch the sand with } \\
\text { their fingers and spread the sand to apply it } \\
\text { to their art work. Provide a simple outline or } \\
\text { have the children draw one art work. Then } \\
\text { they need to paint some glue on their art } \\
\text { work paper with a glue brushes, pinch some } \\
\text { sand with their fingers, and sprinkle it over } \\
\text { the glue. Sprinkle the sand have similar finger } \\
\text { movement with spread gestures. }\end{array}$ & $\begin{array}{l}\text { Spread gesture } \\
\text { (Requires the children to } \\
\text { touch the surface with two } \\
\text { or more fingers and move } \\
\text { them apart) }\end{array}$ \\
\hline
\end{tabular}

\section{Research Method}

\section{Subjects}

One domain expert and two teachers participated in this study. Two teachers were from National Children Development Research Centre (NCDRC), UPSI.

\section{Procedures}

The subjects had been given an explanation about multi-touch gestures design. The multitouch gestures movement also been demonstrated to them by using mobile apps. When they were familiar with the free rotate, pinch and spread gestures, they were having interview 
session. They were required to answer all questions given. The interview consisted of twelve questions and was divided into three sections: Free Rotate, Pinch and Spread. The feedback were collected and analysed qualitatively.

\section{Instruments}

The research instruments used in this study were a set of interview questions.

\section{Results and Discussion}

The purpose of this study is to get expert reviews regarding the children's fine motor skills development by comparing the fine motor skills traditional activities with multi-touch gestures screen design. Table 2, Table 3 and Table 4 summarize the findings based on expert reviews:

Table 2: Domain Expert

\begin{tabular}{|c|c|c|}
\hline Section & Questions & Feedback \\
\hline \multirow{4}{*}{$\begin{array}{l}\text { Free } \\
\text { Rotate }\end{array}$} & $\begin{array}{l}\text { In your opinion, is there any } \\
\text { common between free rotate } \\
\text { gesture on the touch screen with } \\
\text { fine motor skills activities of Van } \\
\text { Gogh Style Finger-Paint? }\end{array}$ & $\begin{array}{l}\text { Expert mentioned the free rotate } \\
\text { gesture and Van Gogh Style Finger- } \\
\text { Paint had similarities which involve } \\
\text { the same moving fingers when } \\
\text { rotate the ball. }\end{array}$ \\
\hline & $\begin{array}{l}\text { In your opinion, can free rotate } \\
\text { gesture on the touch screen help } \\
\text { children to achieve their fine } \\
\text { motor skills as same with } \\
\text { traditional method? }\end{array}$ & $\begin{array}{l}\text { Yes. Expert mentioned that if the } \\
\text { screen was designed for paint } \\
\text { activities and mixing colours it } \\
\text { would just the same as traditional } \\
\text { method. }\end{array}$ \\
\hline & $\begin{array}{l}\text { In your opinion, is there any } \\
\text { common between free rotate } \\
\text { gesture on the touch screen with } \\
\text { fine motor skills activities of } \\
\text { Lavender and Glitter Sensory Salt? }\end{array}$ & $\begin{array}{l}\text { Expert mentioned that free rotate } \\
\text { gesture need to apply all fingers so } \\
\text { that it would be same as Lavender } \\
\text { and Glitter Sensory Salt. }\end{array}$ \\
\hline & $\begin{array}{l}\text { In your opinion, can free rotate } \\
\text { gesture on the touch screen help } \\
\text { children to achieve their fine } \\
\text { motor skills as same with } \\
\text { traditional method? }\end{array}$ & $\begin{array}{l}\text { Expert mentioned that impact of } \\
\text { free rotate gesture on fine motor } \\
\text { skills is in small scale compared to } \\
\text { traditional method. }\end{array}$ \\
\hline \multirow[t]{2}{*}{ Pinch } & $\begin{array}{l}\text { In your opinion, is there any } \\
\text { common between pinch gesture } \\
\text { on the touch screen with fine } \\
\text { motor skills activities of Water } \\
\text { Drops with Suction Cups? }\end{array}$ & $\begin{array}{l}\text { Yes. Expert mentioned the free } \\
\text { rotate gesture and Water Drops } \\
\text { with Suction Cups had similarities } \\
\text { which used same movement of } \\
\text { muscle to pinch the suction cups } \\
\text { and also to pinch the image on the } \\
\text { touch screen design. }\end{array}$ \\
\hline & $\begin{array}{l}\text { In your opinion, can pinch gesture } \\
\text { on the touch screen help children } \\
\text { to achieve their fine motor skills as } \\
\text { same with traditional method? }\end{array}$ & $\begin{array}{l}\text { Yes. Expert mentioned that pinch } \\
\text { gesture help children to achieve } \\
\text { their fine motor skills. }\end{array}$ \\
\hline
\end{tabular}




\begin{tabular}{|c|c|c|}
\hline & $\begin{array}{l}\text { In your opinion, is there any } \\
\text { common between pinch gesture } \\
\text { on the touch screen with fine } \\
\text { motor skills activities of Bean } \\
\text { Gluing? }\end{array}$ & $\begin{array}{l}\text { Yes. Expert mentioned the free } \\
\text { rotate gesture and Bean Gluing had } \\
\text { similarities which used same } \\
\text { movement of muscle. }\end{array}$ \\
\hline & $\begin{array}{l}\text { In your opinion, can free rotate } \\
\text { gesture on the touch screen help } \\
\text { children to achieve their fine } \\
\text { motor skills as same with } \\
\text { traditional method? }\end{array}$ & $\begin{array}{l}\text { Yes. Expert mentioned that pinch } \\
\text { gesture help children to achieve } \\
\text { their fine motor skills. }\end{array}$ \\
\hline \multirow{2}{*}{ Spread } & $\begin{array}{l}\text { In your opinion, is there any } \\
\text { common between spread gesture } \\
\text { on the touch screen with fine } \\
\text { motor skills activities of Pinching } \\
\text { Sand? }\end{array}$ & $\begin{array}{l}\text { Expert mentioned that the use of } \\
\text { spread gesture and Pinching Sand } \\
\text { had similarity in spreading away } \\
\text { two fingers from each other yet } \\
\text { differs in number of fingers used. }\end{array}$ \\
\hline & $\begin{array}{l}\text { In your opinion, can spread } \\
\text { gesture on the touch screen help } \\
\text { children to achieve their fine } \\
\text { motor skills as same with } \\
\text { traditional method? }\end{array}$ & $\begin{array}{l}\text { Teacher mentioned that spread } \\
\text { gesture is limited to two fingers } \\
\text { compared to traditional method. }\end{array}$ \\
\hline
\end{tabular}

Table 3 : Teacher 1

\begin{tabular}{|c|c|c|}
\hline Section & Questions & Feedback \\
\hline \multirow{4}{*}{$\begin{array}{l}\text { Free } \\
\text { Rotate }\end{array}$} & $\begin{array}{l}\text { In your opinion, is there any } \\
\text { common between free rotate } \\
\text { gesture on the touch screen with } \\
\text { fine motor skills activities of Van } \\
\text { Gogh Style Finger-Paint? }\end{array}$ & $\begin{array}{l}\text { Yes. Teacher } 1 \text { mentioned that } \\
\text { children were freely to move their } \\
\text { fingers as their comfort with. }\end{array}$ \\
\hline & $\begin{array}{l}\text { In your opinion, can free rotate } \\
\text { gesture on the touch screen help } \\
\text { children to achieve their fine } \\
\text { motor skills as same with } \\
\text { traditional method? }\end{array}$ & $\begin{array}{l}\text { Teacher } 1 \text { mentioned it was just } \\
50 \% \text { because traditional method } \\
\text { was more or less give adventurous } \\
\text { experience to children through real } \\
\text { touch. }\end{array}$ \\
\hline & $\begin{array}{l}\text { In your opinion, is there any } \\
\text { common between free rotate } \\
\text { gesture on the touch screen with } \\
\text { fine motor skills activities of } \\
\text { Lavender and Glitter Sensory Salt? }\end{array}$ & $\begin{array}{l}\text { No. This is because the children } \\
\text { could not feel the real texture of } \\
\text { sand. Teacher } 1 \text { also mentioned } \\
\text { that the children could not get any } \\
\text { natural experience from free } \\
\text { rotate gesture. }\end{array}$ \\
\hline & $\begin{array}{l}\text { In your opinion, can free rotate } \\
\text { gesture on the touch screen help } \\
\text { children to achieve their fine } \\
\text { motor skills as same with } \\
\text { traditional method? }\end{array}$ & $\begin{array}{l}\text { Teacher } 1 \text { mentioned maybe free } \\
\text { rotate gesture could help for } \\
\text { children who suffer from motor } \\
\text { impairment. }\end{array}$ \\
\hline
\end{tabular}




\begin{tabular}{|c|c|c|}
\hline \multirow{4}{*}{ Pinch } & $\begin{array}{l}\text { In your opinion, is there any } \\
\text { common between pinch gesture } \\
\text { on the touch screen with fine } \\
\text { motor skills activities of Water } \\
\text { Drops with Suction Cups? }\end{array}$ & $\begin{array}{l}\text { Teacher } 1 \text { mentioned that pinch } \\
\text { gesture was more or less just the } \\
\text { same with Water Drops with } \\
\text { Suction Cups due to move two } \\
\text { fingers toward each other. }\end{array}$ \\
\hline & $\begin{array}{l}\text { In your opinion, can pinch gesture } \\
\text { on the touch screen help children } \\
\text { to achieve their fine motor skills as } \\
\text { same with traditional method? }\end{array}$ & $\begin{array}{l}\text { Yes. Teacher } 1 \text { mentioned that } \\
\text { pinch gesture could help children } \\
\text { to achieve their fine motor skills. }\end{array}$ \\
\hline & $\begin{array}{l}\text { In your opinion, is there any } \\
\text { common between pinch gesture } \\
\text { on the touch screen with fine } \\
\text { motor skills activities of Bean } \\
\text { Gluing? }\end{array}$ & $\begin{array}{l}\text { No. This is because the children } \\
\text { could not feel the real texture of } \\
\text { bean by exploring. }\end{array}$ \\
\hline & $\begin{array}{l}\text { In your opinion, can pinch gesture } \\
\text { on the touch screen help children } \\
\text { to achieve their fine motor skills as } \\
\text { same with traditional method? }\end{array}$ & $\begin{array}{l}\text { Teacher } 1 \text { mentioned that pinch } \\
\text { gesture is limited compared to } \\
\text { traditional method. }\end{array}$ \\
\hline \multirow{2}{*}{ Spread } & $\begin{array}{l}\text { In your opinion, is there any } \\
\text { common between spread gesture } \\
\text { on the touch screen with fine } \\
\text { motor skills activities of Pinching } \\
\text { Sand? }\end{array}$ & $\begin{array}{l}\text { There was no common between } \\
\text { spread gesture and Pinching Sand. }\end{array}$ \\
\hline & $\begin{array}{l}\text { In your opinion, can spread } \\
\text { gesture on the touch screen help } \\
\text { children to achieve their fine } \\
\text { motor skills as same with } \\
\text { traditional method? }\end{array}$ & $\begin{array}{l}\text { Teacher } 1 \text { mentioned that pinch } \\
\text { gesture is limited compared to } \\
\text { traditional method due to } \\
\text { exploring their touch journey. }\end{array}$ \\
\hline
\end{tabular}

Table 4 : Teacher 2

\begin{tabular}{|c|c|c|}
\hline Section & Questions & Feedback \\
\hline \multirow{3}{*}{$\begin{array}{l}\text { Free } \\
\text { Rotate }\end{array}$} & $\begin{array}{l}\text { In your opinion, is there any } \\
\text { common between free rotate } \\
\text { gesture on the touch screen with } \\
\text { fine motor skills activities of Van } \\
\text { Gogh Style Finger-Paint? }\end{array}$ & $\begin{array}{l}\text { Teacher } 2 \text { mentioned there is no } \\
\text { common between free rotate } \\
\text { gesture and Van Gogh Style Finger- } \\
\text { Paint because this skills need to use } \\
\text { all fingers while the free rotate } \\
\text { gesture is more relaxed on touch } \\
\text { screen design. }\end{array}$ \\
\hline & $\begin{array}{l}\text { In your opinion, can free rotate } \\
\text { gesture on the touch screen help } \\
\text { children to achieve their fine } \\
\text { motor skills as same with } \\
\text { traditional method? }\end{array}$ & $\begin{array}{l}\text { Teacher } 2 \text { mentioned that free } \\
\text { rotate gesture only used certain } \\
\text { fingers to do the rotation on touch } \\
\text { screen. }\end{array}$ \\
\hline & $\begin{array}{l}\text { In your opinion, is there any } \\
\text { common between free rotate }\end{array}$ & $\begin{array}{l}\text { Teacher } 2 \text { mentioned there is no } \\
\text { common between free rotate }\end{array}$ \\
\hline
\end{tabular}




\begin{tabular}{|c|c|c|}
\hline & $\begin{array}{l}\text { gesture on the touch screen with } \\
\text { fine motor skills activities of } \\
\text { Lavender and Glitter Sensory Salt? }\end{array}$ & $\begin{array}{l}\text { gesture and Lavender and Glitter } \\
\text { Sensory Salt because of low impact } \\
\text { on free rotate gesture compared to } \\
\text { touch on real things. }\end{array}$ \\
\hline & $\begin{array}{l}\text { In your opinion, can free rotate } \\
\text { gesture on the touch screen help } \\
\text { children to achieve their fine } \\
\text { motor skills as same with } \\
\text { traditional method? }\end{array}$ & $\begin{array}{l}\text { Teacher } 2 \text { mentioned that impact } \\
\text { of free rotate gesture on fine } \\
\text { motor skills is in small scale } \\
\text { compared to traditional method. }\end{array}$ \\
\hline \multirow{4}{*}{ Pinch } & $\begin{array}{l}\text { In your opinion, is there any } \\
\text { common between pinch gesture } \\
\text { on the touch screen with fine } \\
\text { motor skills activities of Water } \\
\text { Drops with Suction Cups? }\end{array}$ & $\begin{array}{l}\text { Teacher } 2 \text { mentioned that the use } \\
\text { of pinch gesture and Water Drops } \\
\text { with Suction Cups looked similar } \\
\text { yet differ in their impact which is } \\
\text { pinch gesture do not involve any } \\
\text { real things. Real things are must as } \\
\text { sensorial fundamental at the } \\
\text { beginning of the childhood. }\end{array}$ \\
\hline & $\begin{array}{l}\text { In your opinion, can pinch gesture } \\
\text { on the touch screen help children } \\
\text { to achieve their fine motor skills as } \\
\text { same with traditional method? }\end{array}$ & $\begin{array}{l}\text { Teacher } 2 \text { mentioned that pinch } \\
\text { gesture not really assist on } \\
\text { developing children fine motor } \\
\text { skills compared to traditional } \\
\text { method. }\end{array}$ \\
\hline & $\begin{array}{l}\text { In your opinion, is there any } \\
\text { common between pinch gesture } \\
\text { on the touch screen with fine } \\
\text { motor skills activities of Bean } \\
\text { Gluing? }\end{array}$ & $\begin{array}{l}\text { Teacher } 2 \text { mentioned that the use } \\
\text { of pinch gesture and Bean Gluing } \\
\text { totally different because pinch } \\
\text { gesture do not use any substances. }\end{array}$ \\
\hline & $\begin{array}{l}\text { In your opinion, can pinch gesture } \\
\text { on the touch screen help children } \\
\text { to achieve their fine motor skills as } \\
\text { same with traditional method? }\end{array}$ & $\begin{array}{l}\text { Teacher } 2 \text { mentioned that pinch } \\
\text { gesture is limited compared to } \\
\text { traditional method. }\end{array}$ \\
\hline \multirow{2}{*}{ Spread } & $\begin{array}{l}\text { In your opinion, is there any } \\
\text { common between spread gesture } \\
\text { on the touch screen with fine } \\
\text { motor skills activities of Pinching } \\
\text { Sand? }\end{array}$ & $\begin{array}{l}\text { Teacher } 2 \text { mentioned that the use } \\
\text { of spread gesture and Pinching } \\
\text { Sand had small similarities in the } \\
\text { use of materials but differ in the } \\
\text { originality. }\end{array}$ \\
\hline & $\begin{array}{l}\text { In your opinion, can spread } \\
\text { gesture on the touch screen help } \\
\text { children to achieve their fine } \\
\text { motor skills as same with } \\
\text { traditional method? }\end{array}$ & $\begin{array}{l}\text { Teacher } 2 \text { mentioned that spread } \\
\text { gesture is limited compared to } \\
\text { traditional method. }\end{array}$ \\
\hline
\end{tabular}


Table 5: The summarization of interview findings amongst domain expert and teachers

\begin{tabular}{|c|c|c|c|c|}
\hline $\begin{array}{l}\text { Sectio } \\
\mathrm{n}\end{array}$ & Items & $\begin{array}{l}\text { Domain } \\
\text { Expert }\end{array}$ & Teacher 1 & Teacher 2 \\
\hline \multirow[t]{4}{*}{$\begin{array}{l}\text { Free } \\
\text { Rotat } \\
\text { e }\end{array}$} & $\begin{array}{l}\text { Is there any } \\
\text { common with Van } \\
\text { Gogh Style Finger- } \\
\text { Paint? }\end{array}$ & 1 & 1 & $\begin{array}{c} \\
\text { Should use } \\
\text { all fingers }\end{array}$ \\
\hline & $\begin{array}{l}\text { Does free rotate } \\
\text { gesture help } \\
\text { children achieve } \\
\text { fine motor skills as } \\
\text { this traditional } \\
\text { method? }\end{array}$ & 1 & $\begin{array}{c}\text { / } \\
\text { Traditional } \\
\text { method gives } \\
\text { more } \\
\text { experiences }\end{array}$ & But limited \\
\hline & $\begin{array}{lr}\text { Is there any } \\
\text { common } \\
\text { Lavender with } \\
\text { Glitter } & \text { and } \\
\text { Salt? } & \\
\end{array}$ & $\begin{array}{l}\text { / } \\
\text { Better to use } \\
\text { all fingers }\end{array}$ & $\begin{array}{c}\mathrm{X} \\
\text { No natural } \\
\text { experiences }\end{array}$ & $\begin{array}{c}\mathrm{X} \\
\text { Low impact }\end{array}$ \\
\hline & $\begin{array}{l}\text { Does free rotate } \\
\text { gesture help } \\
\text { children achieve } \\
\text { fine motor skills as } \\
\text { this traditional } \\
\text { method? }\end{array}$ & $\begin{array}{c}\text { / } \\
\text { Small scales }\end{array}$ & $\begin{array}{c}\text { / } \\
\text { Specifically } \\
\text { for those } \\
\text { who suffer } \\
\text { motor } \\
\text { impairment }\end{array}$ & $\begin{array}{c}\text { / } \\
\text { Small scales }\end{array}$ \\
\hline \multirow[t]{4}{*}{ Pinch } & $\begin{array}{ll}\text { Is there any } \\
\text { common with } \\
\text { Water Drops with } \\
\text { Suction Cups? }\end{array}$ & I & / & I \\
\hline & $\begin{array}{l}\text { Does pinch gesture } \\
\text { help children } \\
\text { achieve fine motor } \\
\text { skills as this } \\
\text { traditional } \\
\text { method? }\end{array}$ & I & / & / \\
\hline & $\begin{array}{l}\text { Is there any } \\
\text { common with Bean } \\
\text { Gluing? }\end{array}$ & / & $\begin{array}{c}\mathrm{X} \\
\text { No natural } \\
\text { experiences }\end{array}$ & $x$ \\
\hline & $\begin{array}{l}\text { Does pinch gesture } \\
\text { help children } \\
\text { achieve fine motor } \\
\text { skills as this } \\
\text { traditional } \\
\text { method? }\end{array}$ & / & $\begin{array}{c}/ \\
\text { But limited }\end{array}$ & But limited \\
\hline
\end{tabular}




\begin{tabular}{|c|c|c|c|c|c|}
\hline \multirow[t]{2}{*}{$\begin{array}{l}\text { Sprea } \\
\text { d }\end{array}$} & $\begin{array}{l}\text { Is there } \\
\text { common } \\
\text { Spreading S }\end{array}$ & $\begin{array}{r}\text { any } \\
\text { with } \\
\text { and? }\end{array}$ & 1 & $x$ & \multirow{2}{*}{$\begin{array}{c}/ \\
\text { Small } \\
\text { similarities } \\
/ \\
\text { But limited }\end{array}$} \\
\hline & $\begin{array}{l}\text { Does } \\
\text { gesture } \\
\text { children } \\
\text { fine motor } \\
\text { this tra } \\
\text { method? }\end{array}$ & $\begin{array}{r}\text { spread } \\
\text { help } \\
\text { achieve } \\
\text { skills as } \\
\text { aditional }\end{array}$ & $\begin{array}{c}/ \\
\text { But still } \\
\text { limited as it } \\
\text { only use } 2 \\
\text { fingers }\end{array}$ & $\frac{/}{\text { But limited }}$ & \\
\hline
\end{tabular}

Table 5 shows the summarization of interview findings amongst domain expert and teachers. Majority of the experts agree that there is a common between free rotate, pinch and spread gestures with fine motor skills traditional activities. Conversely some of these activities needed to use all fingers to obtain optimal fine motor skills development such as Van Gogh Style Finger-Paint and Lavender and Glitter Sensory Salt. Teachers also claimed that the Lavender and Glitter Sensory Salt and Bean Gluing were not common with the free rotate and pinch gestures as it has no natural experience and gave low impact to the children as it do not involve any real things. The teacher mentioned that the real things are a must for children experience as sensorial fundamental at the beginning of the childhood.

Additionally, majority of the experts agree that free rotate, pinch and spread gestures can help children achieved fine motor skills development same as the traditional activities but it is limited due to the movement of two fingers only and no natural experiences. Such activities are Van Gogh Style Finger-Paint, Lavender and Glitter Sensory Salt, Water Drops with Suction Cups, Bean Gluing and Spreading Sand.

\section{Conclusion}

The findings of this study is similar to (Razali et al., 2018) which agreed that the multi touch gestures design can help the development of preschool children fine motor skills mainly among 5 and 6 year olds. The findings of this study can be used as approaches for the designers and developers as a result of infrequently used of multi-touch gestures such as free rotate, pinch and spread gestures in pre-school children mobile apps. Most commercialize pre-school mobile apps only applied tap and slide/drag operations (Aziz, 2013). Therefore it is practical for the designers and developers to apply the multi-touch gestures design in mobile apps as it is more beneficial compared to the single-touch gestures when considering the fine motor skills development among pre-school children. Indeed, more efforts are needed to scrutinize the full impact of multi touch gestures design on the development of pre-school children fine motor skills.

\section{References}

Agostinho, S., Tindall-Ford, S., Ginns, P., Howard, S. J., Leahy, W., \& Paas, F. (2015). Giving learning a helping hand: finger tracing of temperature graphs on an iPad. Educational Psychology Review, 27(3), 427-443.

Aziz, N. A. A. (2013). Children's interaction with tablet applications: Gestures and interface design. Children, 2(3), 447-450. 
Crescenzi, L., Jewitt, C., \& Price, S. (2014). The role of touch in preschool children's learning using iPad versus paper interaction. Australian Journal of Language and Literacy, The, 37(2), 86.

Cristia, A., \& Seidl, A. (2015). Parental reports on touch screen use in early childhood. PloS one, 10(6), e0128338.

Dubé, A. K., \& McEwen, R. N. (2015). Do gestures matter? The implications of using touchscreen devices in mathematics instruction. Learning and Instruction, 40, 89-98.

Editors of Child magazine, Developing Motor Skills (2016), Retrieved from http://www.parents.com/toddlers-preschoolers/development/physical/childdeveloping-motor-skills/. on 1st March 2016.

Fine motor skills (2016). Retrieved from http://www.prekinders.com/fine-motor-skills/ on 1st March 2016.

Flewitt, R., Messer, D., \& Kucirkova, N. (2015). New directions for early literacy in a digital age: The iPad. Journal of Early Childhood Literacy, 15(3), 289-310.

Jain, A., Bhargava, D. B., \& Rajput, A. (2013). Touch-screen technology. International Journal of Advanced Research in Computer Science and Electronics Engineering (IJARCSEE), 2(1), pp-074.

Kammer, D., Wojdziak, J., Keck, M., \& Groh, R. (2010). Towards a formalization of multi-touch gestures. Paper presented at the ITS 2010: Meta Gestures, November 7-10, 2010, Saarbrucken, Germany, pp. 49-58.

Katrina Schwartz. Why Kids Need to Move, Touch and Experience to Learn, (2015). Retrieved March, 1, 2016, from http://ww2.kqed.org/mindshift/2015/03/26/why-kids-needto-move-touch-andexperience-to-learn/.

Lin, L. Y., Cherng, R. J., \& Chen, Y. J. (2017). Effect of Touch Screen Tablet Use on Fine Motor

Development of Young Children. Physical \& Occupational Therapy In Pediatrics, 1-11.

Nachiappan, S., Jantan, R., \& Shukor, A. A. A. (2008). Psikologi pendidikan. Oxford Fajar Sdn Bhd.

Omar, A. (2017). Permainan Mudah Alih dan Kanak-kanak. IDEALOGY, 2(1), 137-149.

Razali, F. M., Aziz, N. A. A., Salim, S. A., Rasli, R. M., \& Zulkefly, N. F. (2018). The user experiences of pre-school children on the use of multi touch hand gestures towards fine motor skills: the experts' and teachers' reviews. Journal of Fundamental and Applied Sciences, 10(6S), 582-601. 